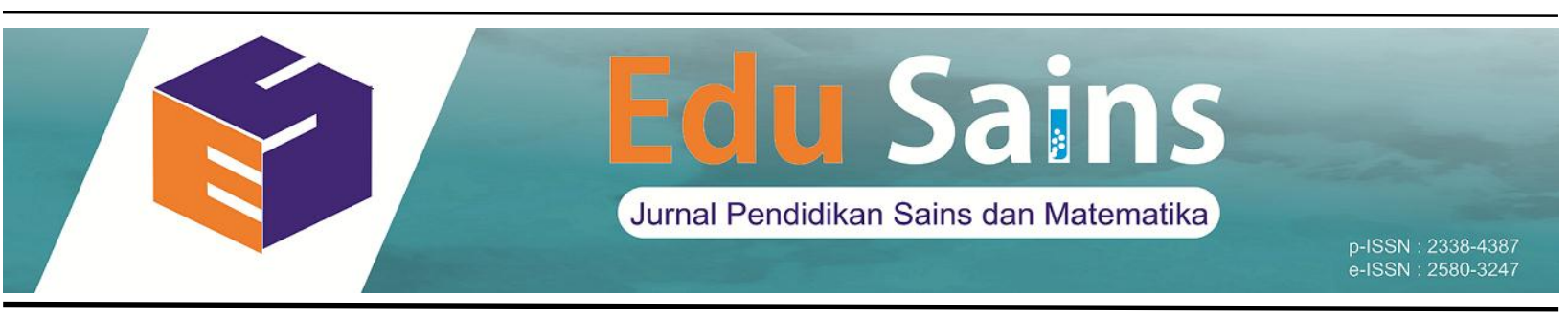

\title{
ANALISIS PENGETAHUAN MAHASISWA PENDIDIKAN FISIKA TENTANG PEMANFAATAN ANGIN SEBAGAI SUMBER ENERGI DI PANTAI SELATAN JAWA
}

\author{
Badriyah Nur Lailia*, Sudarti ${ }^{\mathrm{b}}$ \\ Email : badriyahnurlaili6@gmail.com, sudarti.fkip@unej.ac.id \\ ${ }^{*}{ }^{* b}$ Pendidikan Fisika, Universitas Jember, Jember, Indonesia
}

\begin{abstract}
Abstrak
Tujuan penelitian ini adalah menganalisis pengetahuan mahasiswa pendidikan fisika tentang pemanfaatan angin sebagai sumber energi di pantai selatan Pulau Jawa. Populasi yang ada dalam penelitian ini adalah mahasiswa Pendidikan Fisika Universitas Jember angkatan 2018. Penetuan sampel melalui quota sampling yang terdiri dari 50 mahasiswa. Waktu penelitian yaitu selama bulan desember 2020, dengan instrumen kuisioner yang terdiri dari 8 soal, dengan sumber data primer. Teknik pengumpulan data menggunakan link google form yang disebarluaskan melalui Whatsapp. Teknik analisis data menggunakan deskriptif. Hasil dari penelitian menunjukkan secara keseluruhan aspek pengetahuan mahasiswa mengenai potensi pemanfaatan angin sebagai sumber energi di pantai selatan Pulau Jawa sebesar 70,25 \% yang berada pada kategori cukup, dimana setiap responden memiliki pengetahuan yang berbeda-beda karena konsep yang dimiliki responden juga berbeda-beda. Pengetahuan yang sudah dimiliki mahaisswa ini bisa diterapkan dimasyarakat untuk bisa memberikan peran generasi muda dalam pengembangan sumber energi alternatif dan terbarukan.
\end{abstract}

Kata kunci : pengetahuan mahasiswa pendidikan fisika, pemanfaatan energi angin, sumber energi

\begin{abstract}
The purpose of this study is to analyze the students' of physic education knowledge on the utilization of wind energy resources at the south coast of Java. The population in this study was the students of Physics Education Jember University batch 2018. The sample technique used is quota sampling involving 50 students as respondents. The study was conducted on December 2020, with a questionnaire instrument consist of 8 questions, with primary data sources. The data were collected through google form link disseminated via Whatsapp. The data analysis technique used descriptive. The results of the study indicated that the overall aspect of students' knowledge regarding the potential use of wind energy resources at the south coast of Java is $70.25 \%$ which was classified in sufficient category, where each student has different knowledge because the concepts owned by the students were also different. This knowledge is valuable for young generation to contribute in developing alternative and renewable energy sourcesfor community in the future.
\end{abstract}

Keywords : physics education students knowledge, wind energy utilization, energy sources 


\section{PENDAHULUAN}

Listrik menjadi salah satu kebutuhan yang sangat dibutuhkan untuk masyarakat modern saat ini. Seiring dengan kemajuan teknologi yang sudah tidak dapat dihindari, maka permasalahn dalam dunia listrik yang sering terjadi adalah pemenuhan energi listrik. Jika ketersediaan energi listrik sudah memadai dan tepat sasaran akan meningkatkan laju perkembangan dan pembangunan dari suatu daerah, seperti sektor bisnis, industri, pariwisata, pelayanan umum, dan juga kualitas hidup dari masyarakat. Kebutuhan energi listrik akan semakin meningkat sebanding dengan jumlah penduduk dan aktivitas perekonomi di suatu wilayah tersebut.

Jumlah penduduk yang terus mengalami pertumbuhan dan kegiatan industri yang berkembang pesat memberikan akibat kebutuhan dan pemakain listrik juga mengalami peningkatan dari tahun ke tahunnya (Kartika, 2018). Pertubumbuhan penduduk yang meningkat menyebabkan kebutuhan dari energi listrik juga mengalami peningkatan (Syafriwel, 2015). Sehingga pertumbuhan penduduk yang terus mengalami peningkatan dan industri yang berkembang pesat mengakibatkan meningkatnya kebutuhan listrik yang ada di masyarakat.

Salah satu daerah dengan pertumbuhan penduduk tertinggi di Indonsia adalah Pulau jawa, dimana berdasarkan Badan Pusat Statistika (BPS) 2018 tiga provinsi teratas dengan jumlah penduduk terbanyak di duduki oleh Provinsi Jawa Barat dengan urutan pertama, Provinsi Jawa Timur dengan urutan kedua, dan Provinsi Jawa Tengah dengan urutan ketiga. Selama enam dekade dari kemerdekaan diketahui bahwa Pulau Jawa adalah pulau terpadat, dengan disusul oleh pulau Sumatra, Sulawesi, Kalimantan, Bali dan Nusa Tenggara, Maluku, serta Papua (Mustika, 2011). Semakin besarnya pertumbuhan penduduk yang ada di pulau Jawa ini maka diperlukan juga pemenuhan kebutuhan energi listrik yang semakin besar juga.

Pertumbuhan ekonomi di suatu daerah menunjukkan sejauh mana suatu aktivitas perekonomian memberikan dampak terhadap kesejahtaeraan masyarakat. Indonesia menjadi salah satu negara berkembang di kawasan ASEAN yang aktivitas perekonomiannya mendominasi. Salah satu wilayah di Indonesia yang memiliki aktivitas perekonomian yang tinggi adalah Pulau Jawa. Berdasarkan laporan East Ventures Digital Competitiveness Index 2020 yang mematakan perkembangan perekonomian digital yang berada di Indonesia diketahui bahwa Pulau jawa memiliki nilai daya saing yang tinggi di Indonesia. Dimana Pulau Jawa ini terdiri dari 6 provinsi, yang meliputi Jawa Timur, jawa Tengah, Jawa Barat, Banten, DKI Jakarta, dan DIY Yogyakarta. Selain itu juga Kementrian Perindutrian menyampaikan berita industri pada 9 Maret 2009 bahwa Pulau Jawa masih diandalkan sebagai lokasi untuk mendorong pertumbuhan industri, maka aktivitas perekonomian Pulau jawa cukup tinggi. Pada tahun 2013 konsentrasi industri di Indonesia menunjukkan bahwa pulau jawa memiliki konsentrasi yang sangat tinggi dibandingkan dengan pulau-pulau lainnya (Claudia, 2017). Sehingga aktivitas ekonomi yang tinggi di Pulau Jawa ini memerlkan pemenuhan kebutuhan energi yang tinggi pula.

Berdasarkan laju pertumbuhan penduduk dan aktivitas perekonomian di Pulau Jawa menunjukkan pertumbuhan pemakaian energi listrik yang terus meningkat disetiap tahunnya. Pada tahun 2025 dibutuhkan 130 juta ton batu bara untuk pemenuhan kebutuhan listrik di Pulau Jawa, dimana laju pertumbuhamn industri dan penduduknya bertumbuh sangat pesat. Batu bara tersebut bukanlah jumlah yang sedikit, dan diketahui bahwa batu bara merupakan 
salah satu sumber energi yang tidak terbarukan dan juga merugikan. lingkungan. Karena sumber energi batu bara ini tidak terbarukan, maka suatu saat sumber energi ini akan habis. Selain itu juga penggunaan batu bara untuk pemenuhan kebutuhan listrik juga tidak ramah lingkungan, karena dapat menyebabkan kekurangan air besi, polusi udara tercemar, dan yang lainnya (Budoyo, 2005). Penggunaan batu bara dalam pembangkit listri tidak hanya memberikan dampak positif saja, akan tetapi juga memberikan dampak negatif, dimana dampak negatif tersebut adalah polusi udara yang sangat berbahaya untuk keberlangsungan hidup dari masyarakat (Trianisa, dkk., 2020). Oleh karena itu perlu adanya energi alternatif terbarukan untuk bisa dimanfaatkan di Pulau Jawa yang bisa digunakan untuk mengurangi penggunaan batu bara dalam pemenuhan kebutuhan listrik.

Salah satu potensi sumber daya yang dapat dimanfaatkan di Pulau Jawa untuk pemenuhan energi listrik adalah memanfaatkan potensi angin yang ada di Pantai Selatan Jawa. Dimana potensi angin di Pantai Selatan Jawa ini dapat dimanfaatkan untuk Pembangkit Listrik Tenaga Bayu (PLTB). Pantai selatan Jawa memiliki potensi angin yang sangat tinggi pengembangan energi terbarukan untuk dimanfaatkan sebagai PLTB (Antonov dan Wahyudi, 2018). Berdasarkan Lembaga Penerbangan dan Antariksa nasional (LAPAN) pada 120 titik lokasi, beberapa diantaranya menunjukkan kecepatan angin sebesar $5 \mathrm{~m} / \mathrm{s}$, dimana masingmasing dari daerah tersebut adalah Nusa Tenggara Timur, Nusa Tenggara Barat, Sulawesi Selatan, serta Pantai Selatan jawa (Maidi, 2016).) Kecepatan angin diatas 2,5 m/s berpotensi untuk menghasilkan energi listrik, dimana kecepatan sebesar 2,5 m/s merupakan kecepatan minimum untuk bisa menghasilkan daya dengan kincir TSD 500 dengan jenis bilah inversedtaper (Simamora, dkk., 2019). Sehingga kecepatan angin yang ada di daerah Pantai Selatan Jawa dapat dimanfaatkan salah satunya untuk pembangkit listrik tenaga angin. Perlu adanya pengetahuan mengenai pemanfaatan angin sebagai sumber energi di Pantai Selatan Jawa.

Angin adalah salah satu sumber energi yang mudah untuk dijumpai dalam kehidupan sehari-hari. Angin adalah aliran udara yag terdiri banyak sekali gas di atmosfer bumi. Dimana faktor utama terjadinya angin yaitu rotasi bumi, pemanasan bumi yang tidak merata pada atmosfir, dan juga kondisi permukaan bumi yang tidak rata. Energi angin ini banyak dimanfaatkan oleh manusia seperti untuk ; pompa air, pembangkit listrik, dan yang lainnya. Angin merupakan sumber energi yang terbarukan dan berkelanjutan, serta didistribusikan secara luas dan melimpah (Maidi dan Pribadya, 2015). Dengan memanfaatakan angin untuk sumber energi, maka hal ini berkontribusi dalam mengurangi pencemaran lingkungan. Angin merupakan udara yang mengalami pergerakan secra horisontal yang terjadi karena adanya perbedaan tekanan udara di wilayah tertentu (Wijayanti, dkk., 2015). Angin adalah massa udara yang mengalami pergerakan dari kawasan dengan tekanan maksimum menuju ke kawasan yang memiliki tekanan minimum, dimana untuk dapat menghasilkan energi listrik dari energi angin ini dibutuhkan alat berupa turbin angin, yang mana harapan dengan adanya energi angin untuk pembangkit listrik bisa menjadi solusi untuk menggantikan penggunaan bahan bakar fosil dalam pembangkit listrik (Nurdiyanto, 2020). Sehingga dapat diketahui bahwa angin adalah pergerakan udara akibat dari perbedaan dari suatu wilayah tertentu, dimana angin mengalir dari tempat dengan tekanan tinggi menuju tempat dengan tekanan rendah. Angin bisa dimanfaatkan sebaagi energi alternatif dalam pembangkit listrik. 
Angin dapat dimanfaatkan Pembangkit Listrik Tenaga Bayu (PLTB) sebagai sumber energi alternatif terbarukan. PLTB merupakan salah satu pembangkit listrik yang memiliki efisiensi kerja yang baik dan juga ramah lingkungan dengan cara memanfaatkan sumber daya angin sebagai energi penggerak. Sistem dari PLTB ini yaitu energi gerak dari turbin angin diubah menjadi energi listrik. Pembangunan PLTB di suatu daerah, maka diperlukan studi terlebih dahulu mengenai karakteristik klimatologis angin dari suatu daerah tersebut mengenai ketepatan pembangunan PLTB di suatu daerah (Adhi, 2019). Pembangkit listrik tenaga bayu (PLTB) adalah suatu pembangkit listrik yang mengubah energi dari dorongan angin yang memutar turbin angin, sehingga alternator menghasilkan tegangan listrik, yang mana angin dengan jumlah yang cukup besar yang ada di beberapa daerah di Indonesia bisa dimanfaatkan untuk menghemat penggunaan bahan bakar dari minyak (Mirza dkk., 2019). Maka dapat diketahui bahwa PLTB merupakan pembangkit listrik tenaga bayu atau angin, dimana PLTB ini sebagai sumber energi alternatif yang ramah lingkungan.

Berdasarkan uraian yang telah dijelaskan di atas, diketahui bahwa potensi angin di sepanjang Pantai Selatan Jawa dapat dimanfaatkan sebagai sumber energi berupa PLTB, yang dapat digunakan sebagai pemenuhan kebutuhan listrik masyarakat di Pulau Jawa yang laju pertumbuhan penduduknya dan aktivitas perekonomiannya yang tinggi yang memerlukan pemenuhan kebutuhan listrik yang tinggi pula. Sehingga dengan adanya PLTB dapat mengurangi penggunaan batu bara sebagai sumber energi listrik yang tidak terbarukan dan tidak ramah lingkungan. Maka tulisan ini mengkaji mengenai analisis pengetahuan mahasiswa Pendidikan Fisika tentang pemanfaatan angin sebagai sumber energi di Pantai Selatan Jawa. Tujuan dari tulisan ini yaitu untuk menganalisis pengetahuan mahasiswa Pendidikan Fisika tentang pemanfaatan angin sebagai sumber energi di Pantai Selatan Jawa.

\section{METODE}

Populasi dalam penelitian ini adalah mahasiswa Pendidikan Fisika Universitas Jember angkatan 2018 yang berada pada semester 5, dengan jumlah populasi sebanyak 127 mahasiswa. Metode yang digunakan dalam penelitian ini yaitu quota sampling. Quota sampling adalah pengambilan quota dengan cara nonprobabilitas, dimana menetapkan jumlah sampel yang akan digunakan dan menggunakan sampel dengan cara sembarang sesuai dari persyaratan sebagai sampel, serta pengambilan sampel dengan cara ini digunakan untuk menyelidiki sikap dari suatu sampel atau hubungan antar sampel (Anieting dan Mosugu, 2017). Sampel dari penelitian ini adalah 50 mahasiswa Pendidikan Fisika universitas Jember angkatan 2018 yang berada pada semester 5 .

Penelitian ini menggunakan kuisioner untuk memperoleh data dari responden. Kuisioner atau juga bisa disebut dengan angket merupakan suatu metode pengumpulan data menggunakan seperengkat pertanyaan atau pernyataan tertulis yang diajukan kepada responden (Herlina, 2019). Penyebaran kuisioner dilakuakn dengan menggunakan google form melalui link yang disebar luaskan. Penelitian ini dilakukan selama bulan Desember 2020.

Instrumen kuisioner ini terdiri dari 8 item pertanyaan. Pertanyaan-pertanyaan tersebut untuk menganalisis pengetahuan mahasiswa tentang pemanfaatan angin sebagai sumber energi di sepanjang Pantai Selatan Jawa. Kedelapan pertanyaan tersebut meliputi pembangkit 
listrik yang ramah lingkungan dan terbarukan, prinsip kerja dari PLTB, rata-rata kecepatan angin untuk bisa menggerakkan turbin pada PLTB, cara kerja kincir angin, wilayah pembangunan PLTB, potensi pemanfaatan angin sebagai sumber energi di Pantai selatan Jawa, dan dampak adanya PLTB bagi warga pesisir

Sumber data pada penelitian ini yaitu sumber data primer, dimana sumber data yang diperoleh langsung dari sumber aslinya. Sumber data primer dari penelitian ini yaitu dari hasil pengisian kuisioner oleh mahasiswa Pendidikan Fisika universitas Jember angkatan 2018. Teknik pengumpulan data yang digunakan dalam penelitian ini yaitu dengan cara menggunakan metode survai, dengan cara menyebarluaskan kuisioner kepada responden yaitu mahasiswa Pendidikan Fisika universitas Jember angkatan 2018. Peneliti menyebarluaskan kuisioner dengan cara mengirimkan pesan yang berisi link kuisioner (google form) di Whatsapp grub Pendidikan Fisika universitas Jember angkatan 2018.

Variabel yang ada dalam penelitian ini yaitu variabel bebas (independent) dan variabel terikat (dependent). Dimana pada penelitian ini variabel bebas (independent) adalah konsep materi pemanfaatan angin sebagai sumber energi, serta variabel terikat (dependent) adalah pengetahuan pemanfaatan angin sebagai sumber energi. Dimana variabel terikat dipengaruhi oleh variabel bebas. Sehingga pengetahuan pemanfaatan angin sebagai sumber energi dipengaruhi oleh konsep materi pemanfaatan angin sebagai sumber energi dari setiap respondennya.

Teknik analisis data pada penelitian ini dengan cara deskriptif untuk mengetahui pengetahuan mahasiswa tentang pemanfaatan angin sebagai sumber energi di sepanjang Pantai Selatan Jawa. dimana kategori pengetahuan dari mahasiswa berdasarkan data yang diperoleh akan dianalisis setiap soalnya, dan akan ditentukan presentase untuk setiap opsi jawaban, dan presentase jawaban yang benar dapat dianalisis sesuai kategori pengetahuan berdasarkan:

Tabel 1. Kategori Pengetahuan

\begin{tabular}{ll}
\hline Kategori & Presentase skor Benar \\
\hline Baik & $76 \%-100 \%$ \\
Cukup & $56 \%-75 \%$ \\
Kurang & $\leq 55 \%$ \\
\hline
\end{tabular}

(Sumber : Arikunto, 2013)

\section{HASIL DAN PEMBAHASAN}

Penelitian ini dilakukan untuk menganalisis pengetahuan mahasiswa tentang pemanfaatan angin sebagai sumber energi di sepanjang Pantai Selatan Jawa, dimana dalam penelitian ini dilakukan melalui survai dengan menyebarkan kuisioner kepada mahasiswa mahasiswa Pendidikan Fisika universitas Jember angkatan 2018 semester 5, dengan jumlah responden sebanyak 50 mahasiswa. Dimana dalam kuisioner tersebut terdapat 8 soal yang harus dijawab oleh responden, yang nantinya setiap jawaban benar akan bernilai satu dan setiap jawaban yang salah bernilai nol, yang nantinya untuk jawaban yang benar akan diubah dalam bentuk presentase, dan akan diketahui pengetahuan dari mahasiswa melalui presentase kategori pengetahuan menurut Arikunto (2013). 


\section{Analisis Pengetahuan Mahasiswa tentang PLTB adalah Pembangkit Listrik yang Ramah Lingkungan}

Pembangkit Listrik Tenaga Bayu (PLTB) termasuk pada pembangkit listrik yang ramah lingkungan. Angin merupakan salah satu sumber energi yang dapat dimanfaatakan menjadi pembangkit tenaga listrik, dimana pembangkit listrik tenaga angin inni bisa menjadi solusi untuk mengatasi permasalahan tentang keterbatasan energi. Selain itu juga PLTB ini memiliki keungtungan yaitu berupa sumber energi yang ramah lingkungan dan juga keadaanya melimpah (Hilmansyah, dkk., 2017). Energi angin adalah energi yang dapat dikonversi mejadi tenaga listrik menggunakan generator listrik yang digerakkan dengan kincir angin, dimana energi ini termasuk kedalam energi terbarukan dan ramah lingkungan (Isdiyarto, dkk., 2014). Sehingga PLTB termasuk sumber energi terbarukan karena jumlahanya melimpah, maka dapat dimanfaatkan secara terus menerus hingga tidak terbatas. Dari 50 responden diperoleh jumlah respon terhadap PLTB sebagai pembangkit listrik yang ramah lingkungan dan terbarukan :

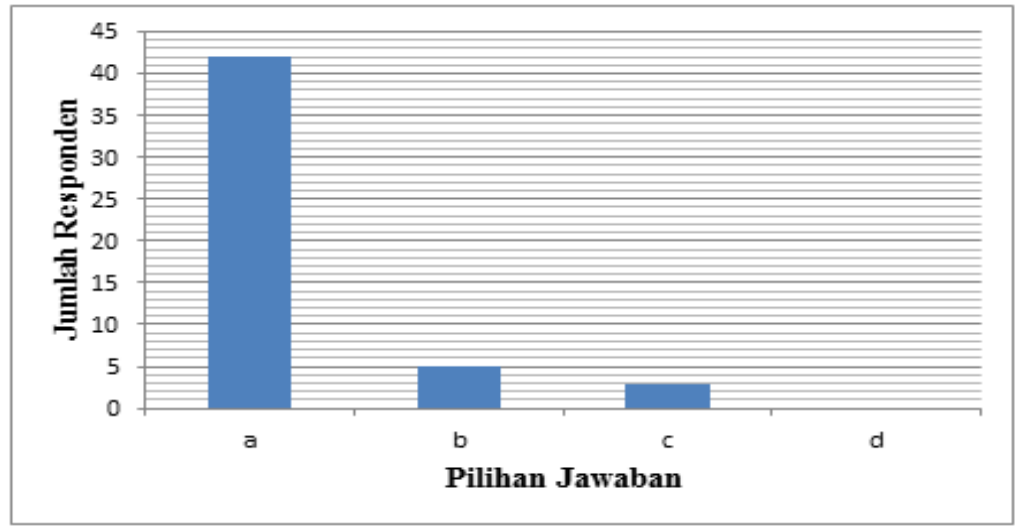

Gambar 1. Diagram batang jumlah responden dalam analisis pengetahuan pembangkit listrik ramah lingkungan

Pilihan jawaban yang tepat untuk PLTB sebagai pembangkit listrik yang ramah lingkungan dan terbarukan adalah a yaitu PLTB adalah pembangkit listrik yang ramah lingkungan, karena angin adalah sumber energi yang terbarukan. Berdasrkan Gambar 1 jumlah rsponden yang memilih jawaban a sebanyak 42 mahasiswa. Dimana presentase dari jawaban yang benar tersebut terhadap jumlah responden yaitu $84 \%$, yang mana presentase tersebut berdasarkan Arikunto (2013) berada pada kategori pengetahuan yang baik. Sehingga mahasiswa memiliki pengetahuan yang baik bahwa PLTB adalah pembangkit listrik yang ramah lingkungan dan terbarukan.

\section{Analisis Pengetahuan Mahasiswa tentang Prinsip Kerja dari PLTB}

Prinsip dari PLTB ini yaitu mengubah energi gerak menjadi energi listrik. Prinsip kerja dari PLTB yaitu memanfaatkan energi kinetik (gerak) angin yang measuk ke dalam area efektif dari turbin untuk memutar baling-baling dari kincir angin, dimana putaran tersebut diteruskan ke generator untuk bisa menghasilkan energi listrik (Adam, dkk., 2019). Pembangkit Listrik Tenaga Bayu (PLTB) yaitu pembangkit listrik yang mengubah energi gerak menjadi energi mekanik, dimana hal ini menyebabkan generator dapat berputar, sehingga menghasilkan arus listrik ( Muhammad dan Djaman, 2019). Maka diketahui bahwa prinsip kerja dari mengubah 
energi gerak menjadi energi listrik. Dari 50 responden diperoleh jumlah respon terhadap prinsip kerja dari PLTB sebagai berikut:

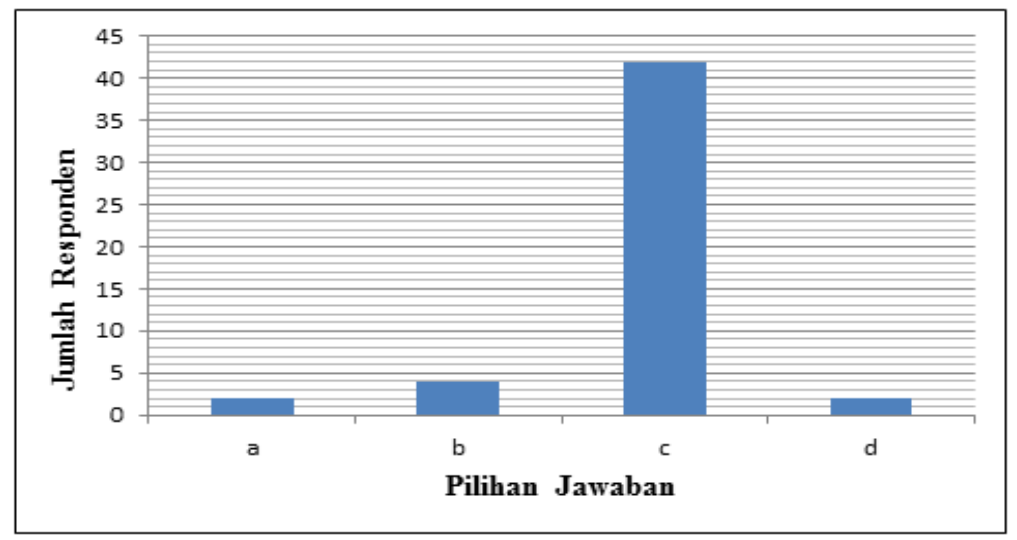

Gambar 2. Diagram batang jumlah responden dalam analisis pengetahuan prinsip kerja PLTB Pilihan jawaban yang tepat untuk prinsip kerja dari PLTB ini yaitu c yang menyatakan bahwa PLTB mengubah energi gerak menjadin energi listrik. Berdasarkan gambar 2 tersebut jumlah responden yang memilih jawaban c sebanyak 42 mahasiswa. Dimana presentase dari jawaban yang benar tersebut terhadap jumlah responden yaitu $84 \%$, yang mana presentasetersebut berdasarkan Arikunto (2013)berada pada kategori pengetahuan yang baik. Sehingga mahasiswa memiliki pengetahuan yang baik mengenai prinsip kerja dari PLTB.

\section{Analaisis Pengetahuan Mahasiswa tentang Rata-Rata Kecepatan Angin yang dapat Menggerakkan Turbin}

Rata-rata kecepatan angin yang bisa digunakan untuk menggerakkan turbin pada PLTB yaiu 5$8 \mathrm{~m} / \mathrm{s}$. Kecepatan angin yang dapat dimanfaatkan sebagai pembangkit listrik tenaga angin atau bayu adalah yang berkecepatan hingga $5 \mathrm{~m} / \mathrm{s}$ pada tegangan $12 \mathrm{volt}$, hal ini sesuai dengan rentang nilai pada alat yang digunakan yaitu 5-8 m/s (Sirad, 2019). Maka diketahui bahwa ratarata kecepatan angin untuk bisa menggerakkan turbin adalah $5 \mathrm{~m} / \mathrm{s}-8 \mathrm{~m} / \mathrm{s}$. Kinerja turbin dari PLTB paling tinggi dengan kecepatan angin sebesar $5.6 \mathrm{~m} / \mathrm{s}$ dengan efisiensi $39.84 \%$ dan daya 39.45 watt pada putaran poros $111 \mathrm{rpm}$ ( Anam, dkk., 2020). Dari 50 responden diperoleh jumlah respon terhadap rata-rata kecepatan angin untuk bisa menggerakkan turbin sebagai berikut: 


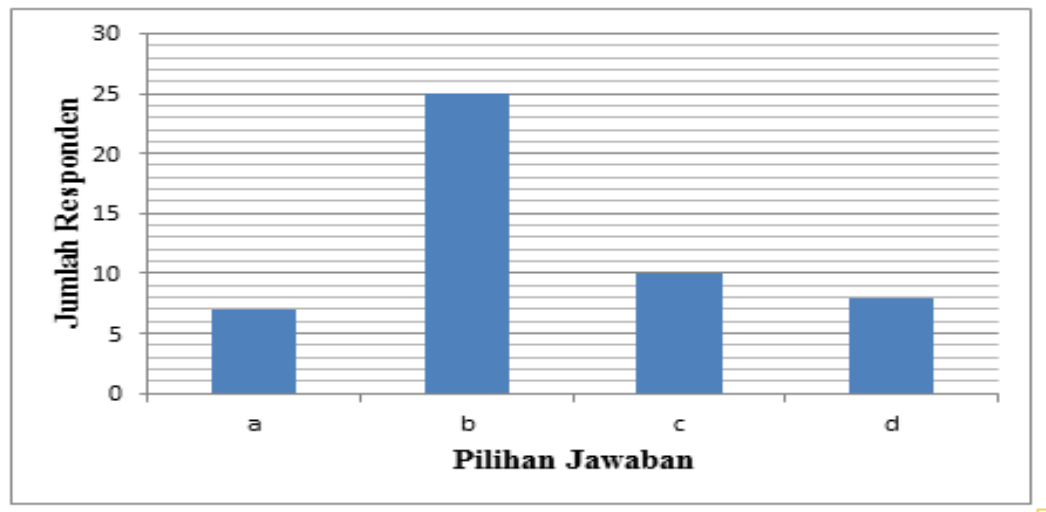

Gambar 3. Diagram batang jumlah responden dalam analisis pengetahuan rata-rata kecepatan angin untuk menggerakkan turbin

Pilihan jawaban yang tepat untuk rata-rata kecepatan angin untuk bisa menggerakkan turbin adalah b yaitu $5 \mathrm{~m} / \mathrm{s}-8 \mathrm{~m} / \mathrm{s}$. Berdasarkian gambar 3 tersebut jumlah responden yang memilih jawaban b yaitu 25 mahasiswa. Dimana presentase dari jawaban yang benar tersebut terhadap jumlah responden yaitu 50\% yang mana presentase tersebut berdasarkan Arikunto (2013 berada pada kategori pengetahuan yang kurang. Sehingga mahasiswa memiliki pengetahuan yang kurang terhadap rata-rata kecepatan angin untuk bisa menggerakkan turbin pada PLTB.

\section{Analaisis Pengetahuan Mahasiswa tentang Cara Kerja Kincir Angin}

Cara kerja dari kincir angin yaitu kincir akan terdorong bergerak akibat adanya aliran angin, sehingga bilah kincir akan memutar poros dari transmisi yang dihubungkan dengan gearbox, selanjutnya di gerabox putaranb poros ditingkatkan dengan cara mengatur perbandingan roda gigi yang berada dalam gearbox. Dimana putaran dari turbin yang telah ditingkatkan sebelumnya akan memutar genrator melalui transmisi. Hal ini mengakibatkan generator menghasilkan listrik (Zulkarnaian, 2018). Dari 50 responden diperoleh jumlah respon terhadap cara kerja turbin sebagai berikut:

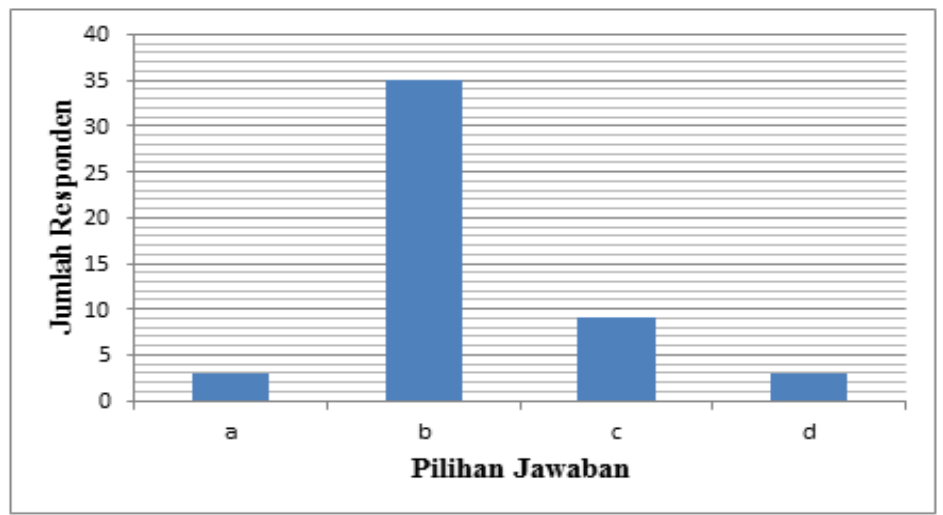

Gambar 4. Diagram batang jumlah responden dalam analisis pengetahuan cara kerja kincir Pilihan jawaban yang tepat untuk cara kerja turbin adalah $b$, yaitu pada tahapan pertama kincir angin memperlambat kecepatan angina dengan menggunakan bilah.Bilah tersebut kemudian dikelilingi oleh angin, dimanaenergi kinetik dikumpulkan oleh bilah tersebut. Setelah itu bilah 
yang dihubungkan dengan poros penggerak berputar pelan dan mengirimkan banyak tenaga ke Gearbox. Gearbox kemudian menyesuaikan tenaga pemutar ini, dan sebagai pengganti berputar secara pelan dengan banyak tenaga di setiap putaran, putarannya menjadi semakin cepat dengan menggunakan tenaga yang sedikit. Pada saat inilah generator yang dihubungkan ke gearbox menghasilkan listrik melalui sekian banyak magnet yang didalamnya terdapat kawat tembaga. Berdasrkan Gambar 4 jumlah responden yang memilih jawaban b adalah 35 mahasiswa. Dimana presentase dari jawaban yang benar tersebut terhadap jumlah responden yaitu 70\%, yang mana presentase tersebut berdasarkan Arikunto (2013) berada pada kategori pengetahuan yang cukup, sehingga mahasiswa memiliki pengetahuan yang cukup mengenai cara kerja kincir angin.

\section{Analisis Pengetahuan Mahasiswa Tentang Fungsi Komponen pada PLTB}

Komponen regulator memiliki fungsi yang tidak kalah pentingnya dengan komponen yang ada pada PLTB lainnya. Fungsi dari regulator dalam pembangkit listrik tenaga angin yaitu untuk meregulasi atau mengatur tegangan keluaran (Sistiawan dan Pamor, 2019). Energi listrik yang dihasilkan oleh generator sebenarnya tidak stabil, karena tegangan yang dihasilkan oleh genarator tergantung pada kecepatan udara yang ada di lokasi PLTB tersebut, oleh karena itu sangat perlu adanya Automatic Voltage Regulator ( AVR ) untuk mengontrol tegangan yang keluar dari generator turbin (Suprihardi, 2016). Sehingga dengan adanya komponen regulator disini tegangan yang awalnya tidak stabil bisa menjadi stabil, sehingga bisa digunakan untuk memenuhi kebutuahan energi. Dari 50 responden diperoleh jumlah respon terhadap fungsi komponen pada PLTB sebagai berikut:

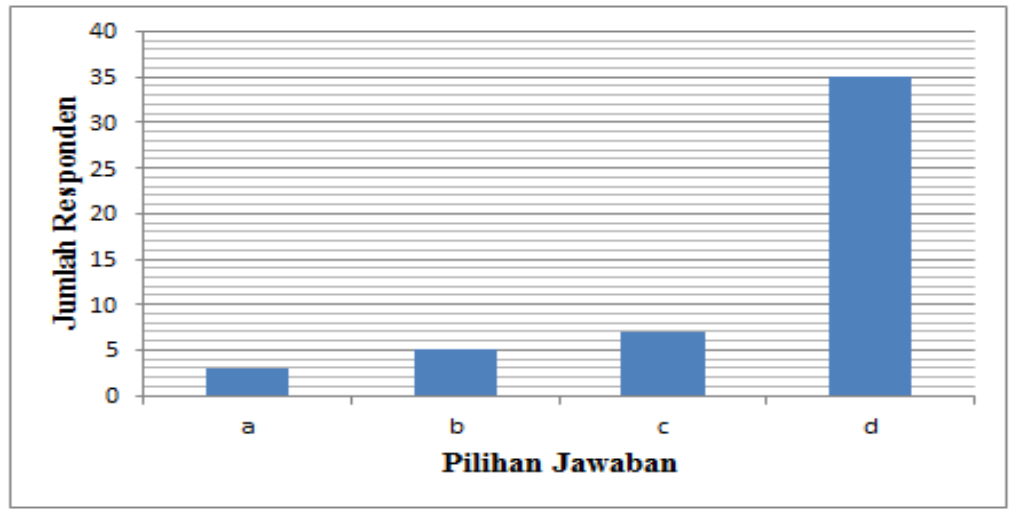

Gambar 5. Diagram batang jumlah responden dalam analisis pengetahuan fungsi kompinen pada PLTB

Pilihan jawaban yang tepat untuk fungi komponen pada PLTB lebih tepatnya mengenai komponen regulator adalah d yaitu angat penting, karena dengan adanya komponen regulator maka energi listrik yang tidak stabil akan diubah menjadi listrik stabil, sehingga tidak akan berbahaya untuk bisa dimanfaatkan oleh masyarakat. Berdasrkan Gambar 5 jumlah responden yang memilih jawaban d adalah 35 mahasiswa. Dimana presentase dari jawaban yang benar tersebut terhadap jumlah responden yaitu $70 \%$, yang mana presentase tersebut berdasarkan 
Arikunto (2013) berada pada kategori pengetahuan yang cukup, sehingga mahasiswa memiliki pengetahuan yang cukup mengenai fungsi komponen pada PLTB.

\section{Analaisis Pengetahuan Mahasiswa tentang Wilayah Pembangunan PLTB}

Wilayah pembangunan PLTB yang tepat yaitu berada di pesisir pantai. Kecepatan rata-rata angin yang tinggi berada di wilayah pesisir bukan di atas bukit (Muhtar, 2019). Pemanfaatan sumber energi angin di Indonesia bisa lebih dikembangkan lagi karena adanya potensi yang melimpah yang berada di daerah pesisir Indonesia (Irfan, dkk., 2019). Sehingga PLTB banyak didirikan didaerah pesisir pantai karena hembusan angin di lepas pantai lebih besar daripada hembusan angin di daratan. Dari 50 responden diperoleh jumlah respon terhadap wilayah pembangunan PLTB sebagai berikut:

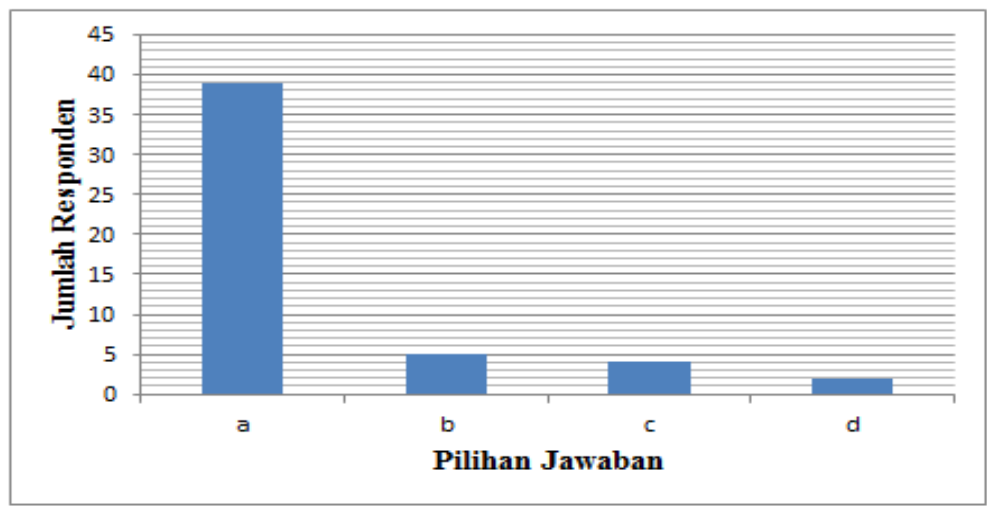

Gambar 6. Diagram batang jumlah responden dalam analisis pengetahuan wilayah pembangunan PLTB

Pilihan jawaban yang tepat untuk wilayah pembangunan PLTB adalah a yaitu pesisir pantai. Berdasarkan gambar 6 tersebutjumlah responden yang memilih jawaban a adalah 39 mahasiswa. Dimana presentase dari jawaban yang benar tersebut terhadap jumlah responden yaitu $78 \%$, yang mana presentase tersebut berdasarkan Arikunto (2013)berada pada kategori pengetahuan yang baik, sehingga mahasiswa memiliki pengetahuan yang baik mengenai wilayah pembangunan PLTB.

\section{Analisis Pengetahuan Mahasiswa tentang Potensi Pemanfaatan Angin di Sepanjang Pantai Selatan Jawa}

Angin yang berada di Pantai selatan Jawa memiliki potensi pemanfaatan sebagai sumber energi. Dimana penelitihan yang dilakukan oleh Parmaputra W., Miftachul Arif, dan Triwahju Hardianto (2015) bahwa kecepatan angin di Pantai Puger Jember yang dapat digunakan adalah 3,5-10,5 m/s mencapai 91,11\%, dimana hal ini memiliki potensi untuk dibangun PLTB dengan ukuran turbin kecil sampai sedang. Pendapat lain dari Martono (2017), yaitu di sepanjang Pantai Selatan Jawa dimana kecepatan angin pada masing-masing perairan yaitu Jawa Barat sebesar 4,7-7,4 m/s, Jawa Tengah yaitu 3,8-6,6 m/s, dan Jawa Timur yaitu 2,7-5,9 m/s. Sehingga jika kecepatan di Pantai Puger Jember memiliki potensi untuk dibangun PLTB dengan ukuran 
turbin kecil sampai sedang, maka dengan kecepatan angin yang berada di Pantai selatan Jawa juga bisa dibangun PLTB.

Selain itu juga Lembaga Penerbangan dan Antariksa Nasional atau LAPAN (2006) menyatakan hasil pemetaan bahwa beberapa wilayah di Indonesia memiliki potensi angin yang dapat dimanfaatkan menjadi sumber energi, dimana salah satu dari wilayah tersebut adalah Pantai selatan jawa. sehingga berdasarkan bebrapa pernyataan diatas, maka angin yang berada di Pantai selatan Jawa dapat dimanfaatakan sebagai sumber energi. Dari 50 responden diperoleh jumlah respon terhadap potensi pemanfaatan angin sebagai sumber energi di Pantai selatan Jawa sebagai berikut:

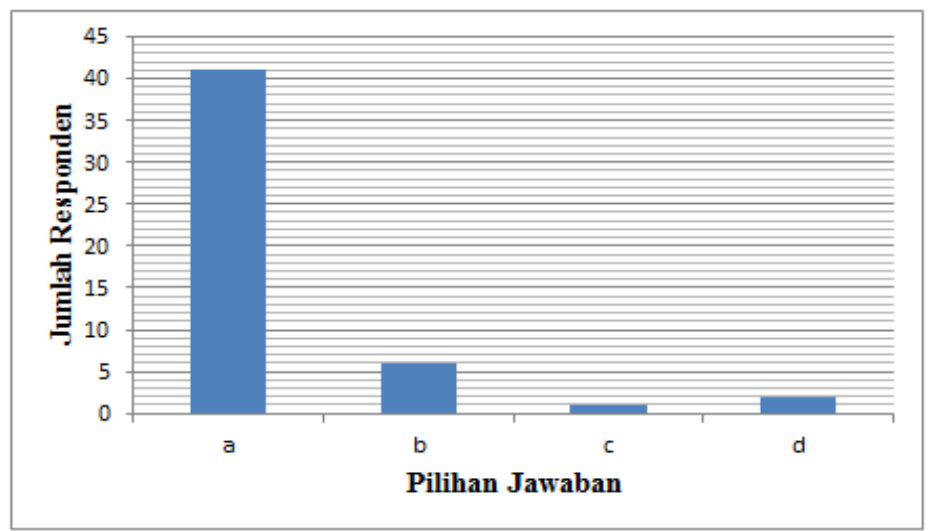

Gambar 7. Diagram batang jumlah responden dalam analisis pengetahuan potensi pemanfaatan angin di sepanjang Pantai Selatan Jawa

Pilihan jawaban yang tepat untuk wilayah pembangunan PLTB adalah a yaitu Bisa, karena potensi angin di wilayah tersebut memenuhi untuk bisa dimanfaatkan sebagai PLTB. Berdasarkan gambar 7 tersebut jumlah responden yang memilih jawaban a adalah 41 mahasiswa. Dimana presentase dari jawaban yang benar tersebut terhadap jumlah responden yaitu $82 \%$, yang mana presentase tersebut berdasarkan Arikunto (2013) berada pada kategori pengetahuan yang baik, sehingga mahasiswa memiliki pengetahuan yang baik mengenai potensi pemanfaatan angin sebagai sumber energi di Pantai selatan Jawa.

\section{Analaisis Pengetahuan Mahasiswa tentang Dampak adanya PLTB bagi Warga Pesisir}

Dampak adanya PLTB bagi warga pesisir tidak hanya berdampak positif juga berdampak negatif, jika kebanyakan yang sering diketahui adalah dampak positif dari adanya PLTB bagi warga pesisir yaitu untuk pemenuhan kebutuhan listrik, tetapi ada juga dampak negatifnya yaitu dengan adanya PLTB ini dapat mengganggu nelayan dalam mengontrol perahu saat sedang melaut karena angin yang tidak beraturan. Hal ini karena nelayan memanfaatkan angin darat dan laut untuk berangkat dan pergi melaut, dimana kincir angin dari PLTB dapat menyebabkan pergerakan udara di pesisir pantai tersebut terganggu. Dari 50 responden diperoleh jumlah respon terhadap dampak adanya PLTB bagi warga pesisir sebagai berikut: 


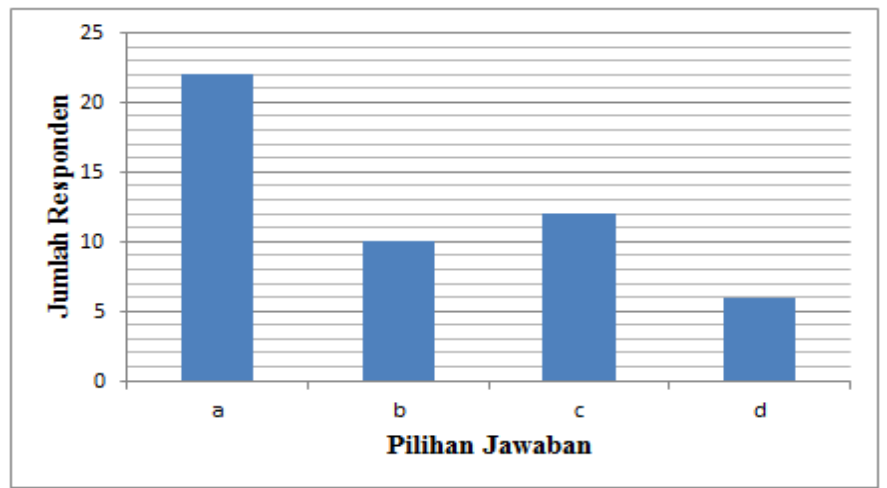

Gambar 8. Diagram batang jumlah responden dalam analisis pengetahuan dampak adanya PLTB bagi warga pesisir

Pilihan jawaban yang tepat untuk dampak adanya PLTB bagi warga pesisir adalah a yaitu mengganggu nelayan dalam mengontrol perahu saat sedang melaut karena angin yang tidak beraturan. Berdasarkan gambar 8 tersebut jumlah responden yang memilih jawaban a adalah 22 mahasiswa. Dimana presentase dari jawaban yang benar tersebut terhadap jumlah responden yaitu 44\%, yang mana presentase tersebut berdasarkan Arikunto (2013)berada pada kategori pengetahuan yang kurang, sehingga mahasiswa memiliki pengetahuan yang kurang mengenai dampak adanya PLTB bagi warga pesisir .

Berdasarkan penjelasan diats aspek pengetahuan mahasiswa Pendidikan Fisika Universitas Jember angkatan 2018 jika dihitung untuk keseluruhan 50 sampel, maka skor jawaban yang benar yaitu :

Tabel 2. Jawaban Benar untuk Masing-Masing Aspek Pengetahuan

\begin{tabular}{clc}
\hline Soal Nomor & \multicolumn{1}{c}{ Aspek Pengetahuan } & Jawaban Benar \\
\hline 1 & Pengetahuan Pembangkit Listrik Ramah Lingkungan & 42 \\
2 & Prinsip Kerja PLTB & 42 \\
3 & Rata-Rata Kecepatan Angin untuk Menggerakkan & 25 \\
4 & Cara Kerja Kincir & 35 \\
5 & Fungsi Kompinen pada PLTB & 35 \\
6 & Wilayah Pembangunan PLTB & 39 \\
7 & Potensi Pemanfaatan Angin di Sepanjang Pantai Selatan Jawa & 41 \\
8 & Dampak adanya PLTB bagi Warga Pesisir & 22 \\
\hline
\end{tabular}

Berdasarkan Tabel 2 tersebut maka total jawaban benar dari 50 sampel adalah 281, yang mana skor maksimal jawaban benar dari 50 sampel adalah 400, sehingga presentase jawaban benar secara keseluruhan 50 sampel adalah 70,25\%. Presentase tersebut menunjuukkan skor berada dalam kategori pengetahuan yang cukup menurut Arikunto (2013). Sehingga diketahui bahwa mahasiswa Pendidikan Fisika Universitas Jember angatan 2018 mempunyai pengetahuan yang cukup mengenai pemanfaatan angin sebagai sumber energi di Pantai selatan Jawa. Hal ini karena setiap mahasiswa Pendidikan Fisika Universitas Jember angkatan 2018 memiliki konsep materi mengenai PLTB ini berbeda-beda, maka pengetahuan yang dimilikinya mengenai PLTB juga berbeda-beda. Pengetahuan yang sudah dimiliki mahaisswa ini bisa diterapkan di 
masyarakat untuk bisa memberikan peran generasi muda dalam pengembangan sumber energi alternatifdan terbarukan kedepannya.

\section{SIMPULAN}

Berdasarkan hasil penelitian ini dapat dianalisis mengenai pengetahuan mahasiswa Pendidikan Fisika tentang pemanfaatan angin sebagai sumber energi di Pantai Selatan Jawa. Dimana bahwa mahasiswa Pendidikan Fisika masih memiliki pengetahuan yang masih kurang dalam menentukan rata-rata kecepatan angin yang bisa untuk menggerakkan turbin, dan juga dampak adanya PLTB bagi warga pesisir. Mahasiswa Pendidikan Fisika memiliki pengetahuan yang cukup mengenai cara kerja dari kincir dan fungsi komponen yang ada pada PLTB. Serta mahasiswa Prendidikan Fisika sudah memiliki pengetahuan yang baik mengenai pembaangkit listrik yang ramah lingkungan dan terbarukan,letak wilayah pembangunan PLTB, dan juga potensi pemanfaatan angin di sepanjang Pantai Selatan Jawa.

Saran dalam penelitian ini yaitu pada populasi penelitiannya yang merupakan mahasiswa pendidikan, sehingga untuk mengetahui pengetahuan dari mahasiswa bisa menggunakan media pembelajaran yang bebasis pembangkit listrik tenaga angin. Selain itu juga untuk bisa meningkatkan pengetahuan mahasiswa Pendidikan Fisika tentang pembangkit listrik alternatif dan terbarukan bisa menggunakan analisis kemmapuan berpikir kritis mengenai permasalahan listrik yang ada di sekitarnya.

\section{DAFTAR PUSTAKA}

[1] Anam, A., Mochtar, A., \& Teguh, R. (2020). Peningkatan kinerja turbin angin vertikal tipe darrieus dengan menggunakan wind gate. Jurnal Flywheel. 11(1) : 6-9.

[2] Adam, M., Harahap, P., \& Nasution, M. R. (2019). Analisa pengaruh perubahan kecepatan angin pada pembangkit listrik tenaga angin (PLTA) terhadap daya yang dihasilkan generator DC. RELE (Rekayasa Elektrikal dan Energi) : Jurnal Teknik Elektro. 2(1) : 30-36.

[3] Anieting, A. E., \& Mosugu, J. K. (2017). Comparison of quota sampling and snowball sampling. Indian Scholar : An International Multidisciplinary Research e-Journal. 3(3) : 33-36

[4] Arikunto, S. (2013). Prosedur penelitian suatu pendekatan praktik. Jakarta: Rineka Cipta.

[5] Bachtiar, A., \& Wahyudi, H. (2018). Analisis potensi pembangkit listrik tenaga angin PT. Lentera Angin Nusantara (LAN) Ciheras. Jurnal Teknik Elektro Itp, 7(1) : 35-45.

[6] Basri, M. H., \& Djaman. (2019). Rancang bangun dan desain prototype pembangkit listrik tenaga bayu model savonius. Jurnal Simetrik, 9(2) : 208-214.

[7] Budoyo. (2005). Perencanaan energi di Indonesia. Jakarta : P3-TKKE Badan Pengkajian dan Penerapan Teknologi.

[8] Claudia, C.A. (2017). Analisis spesialisasi dan konsentrasi spasial industri manufaktur di Indonesia tahun 2007-2013. Jurnal Ilmu Ekonomi. 1(2) : 225-239.

[9] Herlina, V. (2019). Panduan praktis mengelola data kuisioner menggunakan SPSS. Jakarta : PT Elex Media Komputindo.

[10] Hilmansyah, H., Yuniar, R. J., \& Ramli, R. (2017). Pemodelan pembangkit listrik tenaga angin menggunakan kendali PI. Jurnal Sains Terapan, 3(1): 22-26.

[11] Isdiyarto, Henry, A., Sugeng, P. (2014). Model pembangkit listrik tenaga angin dan surya skala kecil untuk daerah perbukitan. Jurnal Sains dan Teknologi (Sainteknol). 12 (1) : 16-22. 
[12] Kartika, S.A. (2018). Analisis konsumsi energi dan program konservasi energi (studi kasus: gedung perkantoran dan kompleks perumahan TI). Jurnal Sebatik. 22(2) : 41-50.

[13] Lubis, Z. (2018). Metode baru merancang sistemmekanis kincir angin pembangkit listrik tenaga angin. Journal of Electrical Technology, 3(3): 163 -166.

[14] Martono. (2017). Karakteristik angin zonal selama upwelling di perairan selatan jawa pada kondisi normal dan enso. Jurnal Meteorologi Dan Geofisika, 18(3) : 125 -132.

[15] Mirza, M., Lubis, R. S., \& Gapy, M. (2019). Pemanfaatan alternator sebagai pembangkit listrik tenaga bayu (PLTB). KITEKTRO: Jurnal Online Teknik Elektro. 4(4) : 19-24.

[16] Muhtar, G.A. (2019). Lokasi Pembangunan Pembangkit Listrik Tenaga Bayu Menggunakan Metode Sig di Provinsi Gorontalo. Jurnal Azimut. 2(2) : 155-164.

[17] Mustika, C. (2011). Pengaruh PDB dan jumlah penduduk terhadap kemiskinan di Indonesia Periode 1990-2008. Jurnal Paradigma Ekonomika. 1(4) : 12-23.

[18] Nurdiyanto, A. (2020). Rancang bangun prototype pembangkit listrik tenaga angin menggunakan turbin angin savonius. Jurnal Teknik Elektro. 9(1): 711-717.

[19] Prasetyo, A. (2019). Studi potensi penerapan dan pengembangan pembangkit listrik tenaga angin di Indonesia. Jurnal Online Mahasiswa teknik Elektro. 4 (1) : 1-12.

[20] Saputra, M. (2016). Kajian literatur sudu turbin angin untuk skala kecepatan angin rendah. Jurnal Mekanova. 2(1) : 74-83.

[21] Saputra, M., \& Pribadyo. (2015). Studi analisis potensi energi angin sebagai pembangkit listrik tenaga angin di kawasan Meulaboh. Jurnal Mekanova. Vol.1. No. 1.

[22] Sirad, M.A.H. (2009). Optimasi sistem pembangkit listrik tenaga angin dan pembangkit listrik tenaga diesel berbasis fuzzy logic. Jurnal PROtek. 6(2) : 102-106.

[23] Simamora, R. P., Handarto, H., \& Saukat, M. (2019). Analisis potensi energi angin dan analisis teknik pembangkit listrik tenaga bayu untuk membangkitkan energi listrik (studi kasus di Gunung Kincir, Desa Ciheras Kecamatan Cipatujah Kabupaten Tasikmalaya). SENTER 2019: Seminar Nasional Teknik Elektro. 91-100.

[24] Sistiawan, Y. A. T., \& Pamor, G. (2019). Perancangan pembangit listrik tenaga hybride (tenaga surya dan tenaga angin) dengan kapasitas 20 W. Sigma Teknika. 2(1) : 49-56.

[25] Suprihardi. (2016). Karakter AVR sebagai penstabil tegangan aplikasi pada generators sinkron, JUrnal LITEK, 13 (1) : 8 -12.

[26] Syarifudin, I., Anton, B. Y. M., \& Agung, K. (2019). Simulasi alat pemantau pembangkit listrik tenaga angin menggunakan mikrokontroler melalui monitor PC. Konvergensi. 13(1).

[27] Syafriwel. (2015). Analisis ramalan kebutuhan beban energi listrik di regional Sumatera Utara tahun 2015-2019 dengan metode gabungan. Jurnal Teknovasi. 2(2) : 53-62.

[28] Trianisa, K., Eko, P. P., \& Aulia, N. K. (2020_. Pengaruh industri batubara terhadap polusi udara dalam keseimbangan world air quality index in India. Jurnal Sains Teknologi \& Lingkungan. 6(2): 156-168. DOI https://doi.org/10.29303/jstl.v6i2.154 .

[29] Widyanto, P., Miftachul, A., \& Triwahju, H. (2015). Aplikasi energi terbarukan melalui pengukuran potensi angin dengan metode analisis weibull pada Pantai Puger Jember. E-Jurnal Arus Elektro Indonesia. Vol 1. No. $1: 31-34$.

[30] Wijayanti, D., Endah, R., \& Imam, S. (2015). Rancang bangun alat ukur kecepatan dan arah angin berbasis arduino uno atmega 328P. Jurnal Inovasi Fisika Indonesia. 4(3) : 150-156. 